Review Paper UDC [7.036:141.13]:82-2Ibsen, H.

doi: $10.21464 / \mathrm{sp} 31107$

Received January $30^{\text {th }}, 2015$

\author{
Nemanja Vujičić \\ Maksima Gorkog 2/18, RS-18000 Niš \\ vnemanja1@gmail.com
}

\title{
Modernist Tradition in Henrik Ibsen's Hedda Gabler and When We Dead Awaken
}

\begin{abstract}
The aim of this paper is to show that Ibsen's plays Hedda Gabler and When We Dead Awaken generally support modernist ideology as summed up in Lionel Trilling's "On the Teaching of Modern Literature" and Toril Moi's Henrik Ibsen and the Birth of Modernism: Art, Theater, Philosophy. Trilling defines the theme of modernist literature as a "quarrel with culture", using as reference Nietzsche's teaching that aesthetics, not ethics, is the primary metaphysical activity of human beings. Trilling further focuses on "primitive" and artistic Dionysian passions this era affirms as inherently human. Moi's study, on the other hand, discusses "aesthetic idealism" of the $18^{\text {th }}$ and $19^{\text {th }}$ centuries, which seems to devaluate that portion of human beings. Having this theoretical background in mind, we can argue that Ibsen announces the modernist era, which dispenses with the idealistic tradition of the $19^{\text {th }}$ century.
\end{abstract}

\section{Keywords}

Henrik Ibsen, modernism, aesthetic idealism, quarrel with culture, Apollo-Dionysus duality

\section{Introduction}

As the title of the paper suggests, Ibsen, or at least his later work (the very end of the $19^{\text {th }}$ century) seems to, if not introduce, then reaffirm modernist ideology. However, in order for us to claim that, we have to be specific about what we mean by 'modernist ideology', which is obviously a broader term than 'modernist literature'. When discussing modernism, i.e. modernist literature, we usually find scholars (such as Randal Stevenson) who will focus on formal aspects of the novel (or the poem), i.e. how it is written so as to express a new tendency in how we experience the world, with the world itself becoming more technologically and industrially advanced, yet "simple" due to its evolving secularity. Traditionally speaking, modernism in literature was "a response" to the manner realist/Victorian novel depicted the world - the depiction being too simplistic because the categories of time and space were too fixed in their linearity, and language too poor in its objective and futile attempt to reflect what is on the outside as opposed to what is on the inside.

While this certainly is one way of dealing with the problem, Toril Moi (2006), in her exhaustive study Ibsen and the Birth of Modernism, focuses on the "idealistic tradition" of the $18^{\text {th }}$ and $19^{\text {th }}$ centuries that modernism dispenses with instead. In the book, she covers not only the novel, or any other literary form, but the overall modernist dialectic between life and art: 
"On closer examination, however, it turns out that he [Michael Bell] means that modernist preferred Marx, Nietzsche, and Freud to Kant, Fichte, and Schelling's theories concerning the relationship between the mind and the world (...) Nevertheless, it was not primarily philosophical idealism that had to collapse for modernism to arise, but the enormously powerful and influential idealist understanding of the nature and purpose of art." (Moi 2006, 69)

What is meant by idealism here has more to do with idealism in art and poetry (aesthetic idealism) than idealism in the philosophical sense, where one is immediately reminded of Kant's transcendental idealism, or German idealism. Still, according to the study, the Romantic ideas Kant, Schiller, Schelling, and Hölderlin shared had an impact on art as well. The Platonic notions of freedom, truth, and beauty were crucial for what was viewed as idealism in art, but were also crucial for the way one perceived and acted upon the world.

Hölderlin believed that the highest act of reason is actually the aesthetic act, where truth and goodness are united in beauty, or, as Schiller put it, "beauty is the product of the accord between the mind and senses" (Moi 2006, 77). This means that art is the means through which genuine human nature, which is always good, is expressed, as opposed to actual human nature, which could be corrupted by material and "sensuous needs". Moi quotes Schiller:

"Every moral baseness is part of human nature as it actually is, but hopefully it is not part of a human nature that is genuine, since this can never be anything but noble."1 (Moi 2006, 77)

This had some implications on how (female) sexuality in particular was regarded, which is important for the plays we will cover. For thinkers such as these, Moi continues, women incarnated human sexuality, so in order to elevate the human above "actuality" women in particular had to be idealized. The context in which the artist creates also had to be deprived of the expression of sensuous/sexual nature, that is, the artist's feelings should be represented as ideal and "pure" love, and in an ideal and pure form. Thus, this split between nature and freedom could be overcome through art, whereby one is offered an image of one's own wholeness; it is only through art that human nature can fully and freely express itself. Following this rule, the discrepancy between aesthetics and ethics seems to disappear. We can see that, ultimately, artistic faculty is ennobling; it is idealistic in the sense that it transcends the mundane, the actual, the natural, in order to give a version of a perfectly free and virtuous humanity.

On the other hand, Trilling (2004), in what could be considered a "late manifesto" of modernism, namely his essay "On the Teaching of Modern Literature", postulates what he believed was the main theme of all modern literature:

"I can identify it by calling it the disenchantment of our culture with culture itself - it seems to me that the characteristic element of modern literature, or at least the most highly developed modern literature, is the bitter line of hostility towards civilization which runs through it." (Trilling 2004, 77)

This "disenchantment of culture with culture itself" is a very general statement about the dissatisfaction with one's civilization, and what was supposed to be considered a modern, progressive society. ${ }^{2}$ The essay suggests that Trilling was one among many who have recognised that ideas of Nietzsche, Marx, and Freud definitely were important for the modernist thought. He mentions some of the seminal works of (pre)modernity, like Frazer's Golden Bough, Nietzsche's The Birth of Tragedy (to be discussed), or Freud's Civilization and its Discontents (published much later than the first two), which seem to acknowledge the above statement in one way or another, and in an almost 
radical fashion. What these works have in common is that they all "quarrel" with culture behind which lies the repression of natural instincts and desires, or simply, if we do not wish to be quite as Freudian as that, quarrel with the culture which failed its own idealistic goals. ${ }^{3}$ Art now turns to criticizing the very culture in which it operates, and modernism turns focus to what is characterized as the irrational, primitive, or if we use the idealist terminology, that which is actual.

"Frazer often speaks quite harshly of the irrationality and orgiastic excesses of the primitive religions he describes (...), because it stands in the way of the rational thought and it can draw man from intellectual participation in the life of society (...). If he deplores the primitive imagination, he also does not fail to show it as wonderful and beautiful." (Trilling 2004, 83)

Despite his aversion to this sort of imagination, Frazer also seems to have validated the old modes of experience modern men wanted to reintroduce in order to escape from "common sense" and "bondage of quotidian fact". It follows that transcendence and ecstasy achieved through drugs, trance, music, orgiastic excesses, or "derangement of the senses", as Rimbaud famously called it, came to be regarded as normal and acceptable manifestations of human nature, ${ }^{4}$ a force resisting culture. According to Nietzsche, these manifestations are the primal source of aesthetic activity, and of overall existence we may add, identified as the Dionysian. ${ }^{5}$

Having this background in mind we will dwell on Ibsen's Hedda Gabler and When We Dead Awaken, both belonging to the same, final series of plays Ibsen wrote at the end of the $19^{\text {th }}$ century. ${ }^{6}$ Both these plays seem to illustrate two aspects of modernist ideology we pointed out; if Hedda Gabler is an affirmation of irrational, yet artistic modes of experience Trilling and Nietzsche talk about, then When We Dead Awaken is a perfect metaphor for the downfall of idealistic vision of art and human nature.

\section{Ibsen and the critique of idealism: Hedda Gabler and the Dionysus-Apollo duality}

As we have already suggested, the cultural climate of the $19^{\text {th }}$ century, and especially the idealist aesthetics, were such that they negated that portion of

1

Schiller's aesthetic theory is known as aesthetic humanism.

2

As an example of a modern society, Trilling takes Mathew Arnold's ideal vision (again given in pretty general and commonsensical terms) of a culture grounded in some timeless intellectual and civic values - it is a society which fosters intellectual freedom and maturity, tolerance, affords sufficient material well-being important for the development of taste, critical spirit, etc... See Trilling 2004, 82 .

3

Trilling says: "But the historic sense of our literature has in mind a long excess of civilization to which may be ascribed the bitterness and bloodiness of the past and of the present and of which the peaceful aspects are to be thought of as mainly contemptible - its order achieved at the cost of extravagant personal repression, either that of coercion or of acquiescence; its repose otiose; its tolerance either flaccid or capricious; its material comfort corrupt and corrupting; its taste a manifestation of either timidity or of pride; its rationality attained only at the price of energy and passion." (Triling 2004, 82)

4

Of course, they are not the only desirable manifestations of human nature and it would be too naive of us to think only in those terms.

5

The Apollonian and Dionysian concepts Nietzsche postulates in his The Birth of Trag$e d y$.

6

Other plays include John Gabriel Borkman, Little Eyolf, and The Master Builder. 
the human nature which was considered irrational, and "immoral". Moi sums up this trend:

"Consciousness must transcend the body; morality, duty, and will must conquer mere material nature." (Moi 2006, 79)

Hedda's angst symbolically represents the new modernist outlook on the nature of art and its relation to culture, but it also gives an insight into what it means to be human behind the cultural facade.

We can argue that Hedda's bizarre behaviour is a reaction to the banality of everyday life - the suffocating culture with its bourgeois morals and marital duties. At first glance, the energy Hedda exudes seems overtly destructive and negative because she is discontented. A conversation with judge Brack illustrates what seems to be Hedda's state of mind.

"Brack: Are you so unlike the generality of women as to have no turn for duties which-?

Hedda: [Beside the glass door.] Oh, be quiet, I tell you! - I often think there is only one thing in the world I have any turn for.

Brack: [Drawing near to her.] And what is that, if I may ask?

Hedda: [Stands looking out.] Boring myself to death. Now you know it...” (Ibsen 1985, 63)

However, we soon realise that that there is, as Ibsen himself said, "deep poetry in the very depths of her soul" (Sæther 2001a, 85) and that her obsession with beauty, in the form of outlandish artistic expression, is the focal point of the play. According to Garton $(1994,121)$, Hedda can be associated with a pagan priestess officiating at a Dionysian rite. Many critics have thus approached the character of Hedda Gabler in terms of the Apollonian and Dionysian duality Nietzsche discusses in The Birth of Tragedy, and for the sake of clarity we will briefly explain what Nietzsche $(2008,19-33)$ says about these two "artistic deities" before applying his ideas to the play(s).

The main idea that lies behind Nietzsche's teaching and this work seems to be that all existence is an "aesthetic phenomenon" and that the primary human's metaphysical activity is aesthetics, not ethics. According to Nietzsche's symbolic description, both the Apollonian and the Dionysian realms stand for two physiological states, those of dream and intoxication, and both these deities are artistic in their own right. They are also in a constant interaction. ${ }^{7}$ Apollo is the god of cognitive powers, but also plastic powers out of which dreams are made of, along with visible art forms such as painting and sculpture. Dionysus, whom we have already mentioned, is the god of intoxication, rapture, orgiastic excess, and the god of non-plastic art form of music. It is through Dionysian rituals - intoxication, sexual promiscuity - that "the productive power of the whole universe" is manifested to "the glorious satisfaction of the primordial One", meaning that one is in such a connectedness with nature that he experiences (re)creation of all existence and affirmation of life through, paradoxically, the annihilation of one's own identity. Apollo, on the other hand, serves to curb such barbaric outbursts of human nature. He stands for what Schopenhauer calls the principium individuationis, or the disintegration of the collective identity among humans, and between humans and nature. This is also the moment where one mediates between the two realms whereby he stops being nature's work of art and becomes the artist. ${ }^{8}$ Nietzsche describes its effect as follows:

"In those Greek festivities a sentimental trait of nature breaks through, so to speak, as if it has reason to lament its dismemberment into individuals." (Nietzsche 2008, 25) 
The Dionysian music of all existence (the underlying will that becomes part of Dionysian revelries) is the music of eternal life despite self-annihilation, or the inevitability of death. This tragic, yet heroic, celebration of life is the Hellenic spirit Nietzsche admired so much.

Following this analogy the controlling and restraining principle - the Apollonian - is represented in a negative light by the aristocratic figure of Hedda's father and bourgeois morals and the duties Hedda abhors (Sæther 2001). Every time her roundish figure (suggesting pregnancy, motherhood) and her husband are mentioned Hedda scowls and retorts in anguish. Hedda's artistic energy, her madness and destructiveness, on the other hand, is the repressed Dionysian realm and it is represented by her former "lover" Løvborg "with vine leaves in his hair". Such an idea can be found in Saether's study as well:

"Both Nietzsche and the modern psychoanalysts point to the connection between discontent, emptiness and melancholy on the one hand and the production of art, creativity on the other. There is a striking likeness between the manic-depressive state and intoxication from wine, ecstasy and inspiration." (Saether 2001b, 435)

Hedda's yearning for beauty is depicted through her and Løvborg's relationship, which was an asexual, platonic affair, just a friendship, according to her words. What was so exciting about it was that Hedda could "peep into a world which she is forbidden to know anything about", that world being, we can assume, Løvborg's life of excesses. It was a simple "craving for life", as Løvborg says, that made their relationship so exciting, and the fact that such a lifestyle is inconsistent with bourgeois morals allows Hedda to experience it only vicariously, i.e. through Løvborg's stories.

"Lovbrog: Yes, that is just what I can't understand-in looking back upon it. But tell me now, Hedda - was there not love at the bottom of our friendship? On your side, did you not feel as though you might purge my stains away-if I made you my confessor? Was it not so?

Hedda: No, not quite.

Løvborg: What was your motive, then?

Hedda: Do think it quite incomprehensible that a young girl — when it can be done-without anyone knowing -

Løvborg: Well?

Hedda: — should be glad to have a peep, now and then, into a world which—?

Løvborg: Which—?

Hedda: — which she is forbidden to know anything about?" (Ibsen 1985, 75)

Consequently, Hedda's only sanctuary seems to be the aesthetic, and her artistic potential is suggested a few times in the play: a writing desk and a

The ideal balance of both realms is achieved in (pre-Socratic) tragedy Nietzsche considers the height of Greek art. With Euripides there comes the decline of tragedy through over-intellectualisation and rationalisation of the artistic intuition. The plots became too realistic and logical, and the tragic, yet life affirming, aspect of existence becomes neglected. This way both the Dionysian and the Apollonian aspects are misused.

8

This might echo Hölderlin's idea that the highest act of reason is the aesthetic act, but despite sharing the same starting point as Schiller, Hölderlin and the likes, namely Ancient Greece, Nietzsche was ambivalent towards the neo-classicist, or idealist mode of experiencing life and art. The poets Schiller called "naive" could be said to be the closest to that Dionysian experience, but still Nietzsche characterizes their art as an "appearance of appearance", an Apollonic illusion. (read: the introduction to Nietzsche: 2001 The Birth of Tragedy, $\mathrm{x}-\mathrm{xxi}$, and chapters 3 and 4). 
piano idly occupy the room (until the last scene) and she burns Løvborg's manuscript after finding out she has not contributed to it in any way. Finally, her obsession with beauty also has its manifestation in her craving to "control someone's life" - the failed attempts to kill Løvborg, the act she does not dare commit because she is a coward. Løvborg serves as a reminder of her repressed actuality and artistic passion, but he also serves as an outlet for it. It could also be suggested that Hedda is a playwright, who stages the play "Løvborg's death" (Moi 2006, 316). In Nietzschean terms, we can interpret this control as her intention to finally "mediate" between the two realms, and Løvborg, being the one whom she wants to control, is regarded as an artistic tool waiting to be spurred into an aesthetic event. However, this play ultimately fails, as Løvborg does not fulfil her aesthetic expectations as, instead of shooting himself in the temple, he probably falls victim to a prostitute who shoots him in the groins.

Hedda's final work is her own death. She retreats to the back room where general Gabler's portrait is hung and she plays a "wild tune" on the piano, suggesting again the Apollonian and Dionysian duality:

"The dance tune before she shoots herself emphasises the battle of the two principles, the Dionysiac, with music as an expression of the vital, the creative, the chaos - and the Apollonian, the control, form and discipline." (Sæther 2001b, 441)

The fact that she commits suicide, "a deed of spontaneous beauty", implies too strong a constraint imposed by her aristocratic past, petty bourgeois morals, but also Brack's unseemly sexual advances and the imminent scandal which would involve her in Løvborg's murder. The aesthetic event, which is her own demise, could be considered the most liberating action she has ever taken. Hedda's suicide, committed in a fit of madness, that "ecstatic state", symbolically reaffirms the Dionysian realm where one annihilates himself. Finally, Trilling finishes his essay with pretty much the same idea:

"I venture to say that the idea of losing oneself up to the point of destruction, or surrendering oneself to experience without regard to self-interest or conventional morality, or escaping wholly from the societal bonds, is an "element" somewhere in the mind of every modern person who dares to think of what Arnold in his unaffected Victorian way called "the fullness of spiritual perfection." (Trilling 2004, 90)

\section{When We Dead Awaken and "the end" of idealist tradition}

In this play that we can clearly see what Moi calls aesthetic idealism questioned by the modernist vitalism Trilling discusses in his essay. ${ }^{9}$ Along with the relationship between Rubek and Irene on the one hand, and Ulfheim and Maia on the other, the central motif of the play is Rubek's sculpture whose (rather equivocal) meaning could be a perfect metaphor for the clash between these two traditions.

The first commentary on the idealistic tradition is given through an important motif we only hinted at when we discussed Hedda Gabler. It is the motif of female self-sacrifice for somebody, usually for a husband, man, or artist. Moi points out that the "pure" woman, desexualized and idealized, needs to prove her purity by sacrificing her life for that somebody (Moi 2006, 318). While in Hedda Gabler the motif is inverted, as she dies triumphantly and of her own accord because she was not willing to be a wife, or a mother for that matter, in When We Dead Awaken the motif is realised in its fullness when Irene is completely submitted to Rubek in her role of a model for the sculpture: 
"Irene: With all the pulsing blood of my youth I served you, but I was a human being in those days (...) and I let it all go you see, gave it up to become a servant to you (...) That was a selfmurder a mortal sin against myself." (Ibsen 1992, 245, 271)

Despite the fact that she reunites with him to take revenge and stab him to death, she will remain loyal to him until the end of the play.

As far as Rubek's sculpture is concerned, it was supposed to be a representation of humanity reborn, personified by "the noblest and purest" woman, unaffected by the world and waking up from death. In order for the sculpture to represent what the author intended, the source of inspiration must not be defiled: Rubek is the epitome of the "idealistic" artist:

"Rubek: To me you became something holy not to be touched but in reverent thought (...) I was filled with the conviction that if I touched you, or desired you sensually my vision would be desecrated that I should never be able to achieve what I was struggling after.” (Ibsen 1992, 246)

However, his idealistic enterprise collapses as the symbolism of the statue takes a strange turn. Rubek is overridden with guilt because he realises how much he has hurt Irene by denying her love and regarding her only as a model, an idea, and not as a woman of flesh and blood. The great marble statue is no longer the central figure of the composition. Rubek puts himself in the centre and adds bizarre human forms with animalistic features to the foundation. The composition now symbolizes a man who has wasted his life by choosing art, the ideal, over life. The beasts, we can argue, represent transfigured humanity deprived of its most humanistic feature - the ability to love and accept the human in all its worldliness. So the statue that was supposed to symbolize ennobled humanity now ironically stands for a failed existence:

"In these works Ibsen return, as is well known, to the pivotal theme of all his late dramas: the antinomy of art and nature. According to these works, the practice of art is only possible through renunciation of "nature" and at the cost of denying one's humanity. Ibsen combines this statement with the question of whether it is worth giving up human happiness, happiness in life, indeed life itself (in the vitalistic sense too) for the sake of art." (Paul 1997, 20)

This other part of the dichotomy, the vitalist part, is given through the characters of Ulfheim, the bear slayer, and Maia, Rubek's present wife. Maia's destiny is similar to Irene's - they are both denied love and sexual recognition. It is very interesting that Ulfheim is compared to a satyr, essentially connected to the Dionysian ritual, and identified as Dionysus' follower. It follows that Ulfhiem stands for the unbridled passion, sexual energy and excess. Maia is hopelessly attracted to Ulfhiem, who also considers himself an artist, only unlike Rubek, he wrestles with and subdues animated material, such as bears and women:

"Ulfheim: You know madam, your husband and I both work with hard materials. I expect he wrestles with his blocks of marble, and I wrestle with the tense quivering sinews of my bears." (Ibsen 1992, 237)

Returning to Nietzsche again we can try to compare how the DionysianApollonian dichotomy (in quite a misbalance though) works in the case of Rubek and Ulfheim. In his denial of Irene as a sexual being, Rubek has denied that vitalist element of the Dionysian energy, the necessary part of the fullness of being achieved through oneness with nature and men. In the case of Maia 
and Ulfheim the satyr, we find the affirmation of the Dionysian passions. We mentioned that Ulfheim is an artist of nature, and its most brutal aspects he subdues. If we imagine the perfect neo-classicist shapes of the Irene sculpture (it is done in marble after all) we shall see Doric art, which is the disciplined, plastic art of Apollo. Nietzsche, himself being a votary of the Dionysian, says "the Apollonian consciousness", as he calls it, is but a thin veil hiding the whole Dionysian realm ${ }^{10}$ (Nietzsche 2008, 26). Hoping that it is not too farfetched a premise, we can say that the transfigured Resurrection Day, with its animalistic forms breaking forward from the base, including the heads of bulls (again a representation of Dionysus), is an inverted image of the Dionysian, of that portion of the human being Rubek finds repelling. The same idea we can find in Johansen (1994):

"In this case, the artist's eye had transformed the sensuality and sexuality of the exposure of the naked female into transcendent, and - in principle - unsexed humanity. The beauty of the body as pure signification. By way of retaliation he becomes overtaken with carnality as beastliness to the point where his artistic powers only serve to expose this feature in man." (Johansen 1994, 111)

This interpretation is in stark contrast with how Nietzsche describes the effect of Dionysian revelries:

"Under the spell of the Dionysian it is not only the bond between man and man which is re-established: nature in its estranged, hostile, and subjugated forms also celebrates its reconciliation with its prodigal son, man. The earth voluntarily gives up its spoils while predators of cliffs and desert approach meekly." (Nietzsche 2008, 22)

Rubek, as we said, laments the fact the he will never be free to live the resurrected life. He will never experience the completeness of being, being severed from Mother Nature, and the sculpture will forever remain the symbol of that loss.

The play finishes climactically. Rubek and Irene, realizing that they have been "dead" for a very long time, decide to go to the mountains and live the rest of their lives "to the fullest". However, they do not go to the base of the mountain like Ulfheim and Maia. They opt for the dizzy heights where they believe they will find salvation. In this fanatical idealistic escape, as we may call it, the avalanche kills them, which suggest that transcendence of the worldly sphere can only be experienced negatively (Paul 1997, 19). Finally, as suggested in (Moi 2006), the avalanche that kills Rubek and Maia symbolically dispenses with the idealistic tradition as well.

\section{Conclusion}

The question is, why did this great humanistic enterprise "collapse" as suggested above, if at all? The task of answering such a question is beyond all doubt complicated. Still, it stands to reason to believe that the cultural climate of the $20^{\text {th }}$ century was much incongruous with the idealist ethic we mentioned above, especially if we take into consideration Lukács' (2000) Marxist critique of modernist aesthetics, ${ }^{11}$ who believed that terminus ad quem of modernist works was indulging in subjectivity, meaninglessness, alienation, and paralysis, or, in a nutshell, psychopathology. Put simply, he condemned the fact that modernism simply rejected reality, the dialectic between human beings and their culture, whereby the possibility of a perfectible reality ceased to exist. A similar view is mentioned in Moi's study as well, according to which modernist literature is primarily autonomous, free from all social, 
political, or religious pressures, and fundamentally concerned with its own aesthetics (Moi 2006, 20). Hedda Gabler could be said to be such a modernist work in the sense that the protagonists are alienated and deeply immersed into their own private worlds. Even Rubek, despite his lunatic idealistic endeavours, is a narcissistic figure concerned with his own ambition and fulfilment, and a figure who, after all, questions the very purpose of art. While this kind of criticism could have a point, especially regarding the works of late modernism, it is still possible to see something invigorating and vital in what is still essentially modernism, at least in Ibsen's case. As suggested by Stanton-Ife (2001), Ibsen's work is still generally concerned with the theme of the human condition, human nature, on the one hand, and culture on the other:

"Ibsen examines the question of being human from a variety of perspectives: contrastively in opposition to the animal and to the divine; ethically in the context of key ethical and social concepts such as rights, duties, happiness and freedom, and above all in terms of the struggle for self-definition." (Stanton-Ife 2001, 240)

It is obvious that, like idealists, Ibsen sees art as a means for the betterment of humanity, only not at the price of depriving that humanity of its core. We can argue that in the plays we covered humanity is idealized, art transcends the mundane and the everyday life, but that there is still something keeping the artistic faculty essentially earthly and bound to the ground, which enables the human nature to manifest itself to the fullest.

\section{References}

Garton, Janet (1994). "The Middle Plays". In: McFarlane, James (ed.), The Cambridge Companion to Ibsen, pp. 106-125. Cambridge: Cambridge University Press. doi: https:// doi.org/10.1017/ccol0521411661.007.

Ibsen, Henrik (1985). Hedda Gabler; The Pillars of the Community; The Wild Duck. Harmondsworth: Penguin Books.

Ibsen, Henrik (1992). When We Dead Awaken. Chicago: Ivan R. Dee.

Johansen, Jørgen Dines (1994). “Art is (Not) a Woman’s Body. Art and Sexuality in Ibsen's When We Dead Awaken". In: VII International Ibsen Conference. Proceedings, pp. 18-47. Oslo: Center for Ibsen Studies.

Lukács, György (2000). "The Ideology of Modernism". Available at: http://courseweb. stthomas.edu/ajscheiber/engl\%20380/Georg\%20Lukacs.pdf (accessed on January 30, 2015).

Moi, Toril (2006). Henrik Ibsen and the Birth of Modernism: Art, Theatre, Philosophy. Oxford: Oxford University Press.

Nietzsche, Friedrich (2008). The Birth of Tragedy. Oxford: Oxford University Press.

Paul, Fritz (1997). "Metaphysical Landscapes in Ibsen’s Late Plays”. In: Hemmer, Bjørn, Ystad, Vigdis, Ewbank, Inga Stina (eds.), Contemporary Approaches to Ibsen, vol. IX, pp. 17-34. Oslo: Scandinavian University Press.

Sæther, Astrid (2001a). "Hedda Gabler - a Modern Woman: On Melancholy and Creativity”. Studia Universitatis Babes-Bolyai XLV (3/2001), pp. 83-94.

10

In the context of the Apollonian Greeks watching the votaries of Dionysus in awe, and realizing in fear that those outburst of human nature are not alien to them after all.
11

He much favoured the realist novel, and criticized mostly absurdist authors such as Kafka or Beckett, but also the fathers of early modernism such as T. S. Eliot. 
Sæther, Astrid (2001b). "Beauty - Discontent - Nothingness: Hedda Gabler and Nietzschean Concepts of Creativity”. In: Bjørby, Pål, Aarseth, Asbjørn (eds.), IX International Ibsen Conference. Proceedings, pp. 433-441. Øvre Ervik: Alfheim \& Eide.

Stanton-Ife, Anne-Marie (2001). "Identity, Suicide and Tragedy in Hedda Gabler". In: Bjørby, Pål, Aarseth, Asbjørn (eds.), IX International Ibsen Conference. Proceedings, pp. 239-247. Øvre Ervik: Alfheim \& Eide.

Trilling, Lionel (2004). “On the Teaching of Modern Literature”. In: Petrovic, Lena (ed.), Literature, Culture, Identity: Introducing XX Century Literary Theory, pp. 77-90. Niš: Prosveta - Filozofski fakultet.

Williams, Raymond (1968). Drama from Ibsen to Brecht. London: Chatto \& Windus.

\section{Nemanja Vujičić}

\section{Modernistička tradicija u djelima Hedda Gabler i Kada se mi mrtvi probudimo Henrika Ibsena}

\section{Sažetak}

Cilj je rada pokazati da Ibsenove drame Hedda Gabler i Kada se mi mrtvi probudimo općenito podržavaju modernističku ideologiju, kao što su to sumirali Lionel Trilling $u$ eseju »On the Teaching of Modern Literature «e Toril Moi u knjizi Henrik Ibsen and the Birth of Modernism: Art, Theater, Philosophy. Trilling određuje temu modernističke literature kao »prepirku s kulturom «, koristeći kao referencu Nietzscheov nauk da je estetika, a ne etika, primarna čovjekova metafizička aktivnost, s fokusom na "primitivne" $i$ umjetničke dionizijske strasti, koje to razdoblje priznaje kao ljudima urođene. Moijeva studija, s druge strane, razmatra »estetički idealizam« 18. i 19. stoljeća, za kojeg se čini da obezvređuje taj dio čovjeka. Imajući ovaj teorijski okvir u vidu, možemo tvrditi da Ibsen najavljuje modernističko doba koje raskida s idealističkom tradicijom 19. stoljeća.

\section{Ključne riječi}

Henrik Ibsen, modernizam, estetički idealizam, prijepor s kulturom, dualizam Apolon-Dioniz

\section{Nemanja Vujičić}

\section{Modernistische Tradition in Henrik Ibsens Hedda Gabler und Wenn wir Toten erwachen}

\section{Zusammenfassung}

Das Ziel dieser Arbeit ist zu zeigen, dass Ibsens Dramen Hedda Gabler und Wenn wir Toten erwachen im Allgemeinen die modernistische Ideologie unterstützen, wie es in Lionel Trillings On the Teaching of Modern Literature und Toril Mois Henrik Ibsen and the Birth of Modernism: Art, Theater, Philosophy resümiert wird. Trilling definiert das Thema der modernistischen Literatur als „Streit mit Kultur", indem er sich als Referenz der Lehre Nietzsches bedient, die Ästhetik, und nicht die Ethik, sei die primäre metaphysische Tätigkeit des Menschen, mit dem Schwerpunkt auf den ,primitiven " und künstlerischen dionysischen Leidenschaften, die diese Ära als von Natur aus menschlich bestätigt. Mois Studie hingegen erörtert den „ästhetischen Idealismus" des 18. und 19. Jahrhunderts, welcher diesen Teil des Menschen abzuwerten scheint. Indem wir diesen theoretischen Hintergrund im Sinn behalten, können wir die Ansicht vertreten, dass Ibsen die modernistische Ära ankündigt, die sich von der idealistischen Tradition des 19. Jahrhunderts trennt.

\section{Schlüsselwörter}

Henrik Ibsen, Modernismus, ästhetischer Idealismus, Streit mit Kultur, Apollo-Dionysos-Dualität 


\title{
Nemanja Vujičić \\ La tradition moderniste dans les œuvres Hedda Gabler et Quand nous nous réveillerons d'entre les morts d'Henrik Ibsen
}

\begin{abstract}
Résumé
Cet article a pour intention de montrer que les xuvres Hedda Gabler et Quand nous nous réveillerons d'entre les morts d'Ibsen soutiennent de manière générale l'idéologie moderniste dépeinte dans On the Teaching of Modern Literature de Lionel Trilling, mais également dans Henrik Ibsen and the Birth of Modernism: Art, Theater, Philosophy de Toril Moi. Trilling définit le thème de la littérature moderniste comme "querelle avec la culture » s'appuyant sur les enseignements de Nietzsche où l'esthétique, et non l'éthique, est la principale activité métaphysique de l'homme et se concentre sur les passions " primitives 》 et artistiques dionysiaques qui, à cette époque, été considérées comme inhérentes à l'homme. D'un autre côté, l'étude de Moi traite de "l'idéalisme esthétique » du XVIII et XIX siècle et semble dévaloriser cette partie de l'homme. Ayant à l'esprit ce contexte théorique, nous pouvons affirmer qu'Ibsen annonce l'ère moderniste rompant avec la tradition idéaliste du XIX siècle.
\end{abstract}

\section{Mots-clés}

Henrik Ibsen, modernisme, esthétique, idéalisme, querelle avec la culture, dualité de l'apollinien et du dionysien 